AUSTRALIAN JOURNAL OF BASIC AND APPLIED SCIENCES

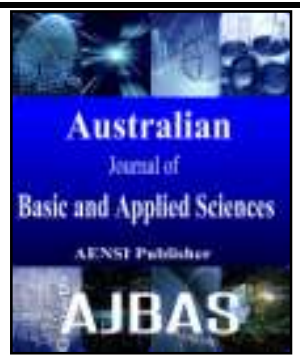

\title{
Behavior of Varieties of Rice Spotted Seeds (Oryza sativa L.) from The San Miguel Area, Misiones-Paraguay
}

${ }^{1}$ Yesmina Lezcano Aquino, ${ }^{1}$ Gerald Sormanti Valenzuela, ${ }^{2}$ Víctor Gómez López, ${ }^{1}$ Johana González Vera, ${ }^{1}$ Pamela Peña Alvarenga, ${ }^{3}$ Humberto Sarubbi

${ }^{1}$ Laboratorio de Análisis de Calidad de Semillas, Área de Producción Agrícola, Facultad de Ciencias Agrarias, Universidad Nacional de Asunción, San Lorenzo, Central, Paraguay.

${ }^{2}$ Laboratorio de Entomología. Área de Protección Vegetal, Facultad de Ciencias Agrarias, Universidad Nacional de Asunción, San Lorenzo, Central, Paraguay.

${ }^{3}$ Área de Protección Vegetal, Facultad de Ciencias Agrarias, Universidad Nacional de Asunción, San Lorenzo, Central, Paraguay.

\section{Address For Correspondence:}

Yesmina Lezcano Aquino, Laboratorio de Análisis de Calidad de Semillas, Área de Producción Agrícola, Facultad de Ciencias Agrarias, Universidad Nacional de Asunción, San Lorenzo, Central, Paraguay,

E-mail: lab.semillas@agr.una.py.

\section{ARTICLE INFO}

\section{Article history:}

Received 10 August 2017

Accepted 1 October 2017

Available online 18 October 2017

Keywords:

seed quality, spotted, pathogens,

Oryza sativa.

\begin{abstract}
A B S T R A C T
The spotted seeds produced by a complex of fungi can affect components of the yield and the quality of the seed, thus diminishing the production and therefore causing economic losses. A better understanding of the damage caused by this disease makes it possible to determine the most suitable varieties to use, pathogen inoculum thresholds in rice seeds that can cause economic losses, and helps us establish permissible levels as healthy seeds in batches. This research was carried out in the Laboratory of Seeds Quality Analysis of the Faculty of Agrarian Sciences of the National University of Asunción, Paraguay, in 2016, with the objective of evaluating the effect of spotted seeds on the quality of lots coming from the area of San Miguel, Misiones department. For the experiment, a completely randomized experimental design was used, and four batches of $O$. sativa seeds of the varieties IRGA 424, IRGA 426, IRGA 428 and PUITA were used. First, a batch characterization was carried out to determine the percentage of spotted seeds using the methodology described by Cárdenas et al. (2004), and the weight of one thousand seeds, germination and viability for both, non-spotted seeds and spotted seeds, were then evaluated following the methodology proposed by ISTA (2011). The results obtained indicate that: as for the percentage of spotted seeds, there were no differences between batches, with levels from $11.65 \%$ to $19.16 \%$; for the weight of a thousand seeds there are differences between the non-spotted seeds in relation to the spotted, presenting a decrease of up to $27 \%$ for the variety PUITA; in the germination it was observed differences between the spotted and non-spotted seeds, the latter presenting the highest values of up to $94 \%$ for PUITA and IRGA 424 varieties. In respect to viability, it was observed that within the group of non-spotted seeds varieties higher percentages were showed by the variety IRGA 424, followed by the IRGA 426, being the most affected by the spotted in glumes the variety PUITA with the lowest percentage of said variable. The spotted seeds caused by a complex of pathogenic fungi significantly affects the weight variables as well as germination and viability of the rice seeds (Oryza sativa L.) corresponding to the varieties of IRGA 424, IRGA 428, IRGA 426 and PUITA. The IRGA 424 rice variety shows better performance on spotted behavior in terms of germination and viability.
\end{abstract}

Open Access Journal

Published BY AENSI Publication

(C) 2017 AENSI Publisher All rights reserved

This work is licensed under the Creative Commons Attribution International License (CC BY). http://creativecommons.org/licenses/by/4.0/

\section{(C) 0 open Access}

To Cite This Article: Yesmina Lezcano Aquino, Gerald Sormanti Valenzuela, Víctor Gómez López, Johana González Vera, Pamela Peña Alvarenga, Humberto Sarubbi., Behavior of Varieties of Rice Spotted Seeds (Oryza sativa L.) from The San Miguel Area, MisionesParaguay. Aust. J. Basic \& Appl. Sci., 11(13): 80-85, 2017 


\section{INTRODUCTION}

The Paraguayan agriculture plays a very important role in the development of the country, it has an $18.85 \%$ share in the national economy. However, adding to the other sectors involved in the production chains, that number rises to $28.9 \%$, about one-third of Paraguay's total economy (Ministerio de Agricultura y Ganaderia MAG, 2016).

Rice cultivation has experienced a very important growth and expansion, where the increase of the volume favored the industrial investments in which the natural product is processed to obtain diverse of products. In the year 2010 exports were around 60 million of dollars, passing to more than 165 million of the same currency in the last few years (Investor, 2015).

In the period 2015-2016, the production of national irrigated rice generated approximately 858,000 tons in about 130 thousand hectares planted in the Eastern Region, being the departments of greater representativeness Itapúa, Misiones and Caazapá. It was $6,600 \mathrm{~kg} / \mathrm{ha}$, which represented a surface increase of $1.6 \%$ in the ground in relation to previous years (MAG, 2016).

The achievement of higher yields is limited by several causes, including the incidence of diseases such as spotted of grains produced by complex fungi that can cause severe damage (Estrada and Sandoval cited by Cárdenas, 2004; Aguilar cited by Regla et al. 2004).

It is worth mentioning that seeds are the main vehicles for spreading life. However, in their mission of being carriers of genetic, agronomic and morphological characteristics can also serve as transmitters of pathogens (Arriagada, 2000).

The disease of spotted seeds is of increasing importance in rice cultivation, due to its wide distribution observed in the last agricultural campaigns. Currently, it is present in most of the rice producing regions of the world. Taking this into account, research shows that the cause of this disease is mainly of fungal origin, where more than one fungal species is detected for each growing region. Some of the major fungi associated with spotted grain are Cladosporium spp., Curvularia spp., Drechslera spp., Fusarium spp., Bipolaris sp., Nigrospora sp., Pyricularia sp., Alternariasp, among others (Rivero et al. 2012; Pineda et al. 2007; Gutierrez and Mazzanti, 2001).

The damage caused by pathogens associated with spotted grain of the rice can appear externally on the glumes internally on the endosperm or both. On the glumes lesions vary from very small spots until the total coverage of the same obtaining a brown color (Castaño, 1985).

The fact that the disease can be externally evident on glumes, internally on the endosperm, or in both, suggests that the microorganisms involved are pathogens associated with seeds, since these constitute a suitable means for them to survive from one generation to another and spread from one geographical area to another; even those healthy and disinfected seeds as they can carry structures of microorganisms inside (Batalla, 2014).

This disease affects yields components by causing germination to regress and decrease, seedling vigor and size, number of grains per panicle, grain weight and grain filling. In addition to decreasing the quality of the seeds, reducing the number of whole grains and to increasing the brittle grains in the mill process like the gypsum grains and abnormal color (Pinciroli et al., 2004).

Among the determining conditions for the appearance of "Spotted Grains" in rice, we can mention; abundant rainfall, high hours of wet foliage, average relative humidity close to $90 \%$, low solar radiation and average daily temperature in the order of $25^{\circ} \mathrm{C}$. In addition, it should be noted that the severity of the disease in the field depends on the rice variety, the causative microorganism, predisposing factors and the moment of inoculation, and that if it occurs when the panic emerges, they cause the greatest damages.

In the 2015/2016 season it was marked by the presence of moderate to strong children (rainfall) that had an impact on agricultural production with rainfall above normal values (rainfall from 1800 to $2000 \mathrm{~mm}$ ), especially in spring and summer, which was a determinant for the increase of the field disease (MAG, 2016).

Among the established phytosanitary strategies, at different stages of cultivation, we can find preventive foliar applications, chemical treatments of seeds, use of certified seeds and the use of a tolerant or resistant variety. (Perez et al., 2002; Morejón et al., 2005).

The objective of this work was to evaluate the effect of spotted seeds on the quality of lots coming from the area of San Miguel, Misiones department.

\section{METHODS AND MATERIALS}

The experiment was performed with four lots of $O$. sativa seeds, varieties IRGA 424, IRGA 426, IRGA 428 and PUITA, coming from San Miguel, Department of Misiones, harvested 2015/2016. While the tests were carried in the Laboratory of Seed Quality Analysis FCA/UNA, Paraguay in 2016. The experimental design used was from completely randomized with 4 treatments and 4 replications. 


\section{Percentage of spotted seeds}

Prior to the determination of different variables, in order to characterize of each batch of seeds and according to the spotted percentage, $70 \mathrm{~g}$ of seeds were taken and classified in two fractions, spotted and nonspotted seeds. In the case of spotted seeds, account was taken with spotted glumes having at least $20 \%$ of the area affected. The percentage of spotted was calculated by formula (Cárdenas et al., 2004).

Spotting $(\%)=\mathrm{M} /(\mathrm{S}+\mathrm{M}) \ldots \times 100$

M: Number of spotted seeds; $\mathbf{S}$ : Number of non-spotted seeds.

\section{Weight of 1000 seeds}

In order to determine the weight of 1000 seeds, the calculation was performed by random counting of 8 replications of 100 seeds each, then weighed in a digital scale with precision of 3 decimals. The result was obtained by finding the average of the eight replicates and the same was expressed in grams.

\section{Germination test}

To determine the germinative power, spotted seeds and non-spotted seeds were sown using 200 seeds of each fraction, divided into 4 replications of 50 seeds, sown in rolls of germitest paper sterilized at $105^{\circ} \mathrm{C}$ for 30 minutes, using one of them as a base and the other as a lid, they were moistened with distilled water in a proportion $1: 3$ in relation to the weight of the dry paper, the incubation temperature was $25^{\circ} \mathrm{C}$, evaluation of normal seedlings were carried out 14 days after sowing. Normal seedlings were considered those that had all the fully developed essential structures. The results were expressed in percentage of normal seedlings.

\section{Viability test}

The viability of seeds was obtained in two fractions of each batch, using tetrazolium $1 \%$, initially prehumidified during 18 hours in an incubator at $20^{\circ} \mathrm{C}$, later transferred at a temperature of $30{ }^{\circ} \mathrm{C}$ with the solution of tetrazolium and maintained in these conditions for 2 hours. The evaluation was made by a longitudinal cut and taking into account the seeds with the embryo dyed in carmine red. The results were expressed in percentage of viable seeds.

\section{Analysis of data}

The data were subjected to an analysis of variance (ANOVA) and the comparison of means by the Tukey test at $5 \%$ of error probability. For the germination and viability analyzes, data transformation was performed $\operatorname{using} \sqrt{x}$.

\section{RESULTS AND DISCUSSION}

\section{Percentage of spotted seeds}

The results obtained for the determination of the spotted percentage are observed in Table 1. They indicate that there were no significant statistical differences for this variable among the different rice varieties used in this research.

Table 1: Percentage of spotted seeds of the different rice varieties. FCA - UNA. San Lorenzo, Paraguay 2017.

\begin{tabular}{ccc}
\hline TREATMENT & DESCRIPTION & SPOTTED (\%) \\
\hline T3 & IRGA 428 & $19,16 \mathrm{a}$ \\
T2 & IRGA 424 & $16,38 \mathrm{a}$ \\
T4 & IRGA 426 & $13,82 \mathrm{a}$ \\
T1 & PUITA & $11,65 \mathrm{a}$ \\
\hline *means with the
\end{tabular}

*means with the same letters do not differ from each other $(\mathrm{p}>0,05)$ by the Tukey test at $5 \%$ of probability of error.

All the varieties showed a moderated resistance to the spotted of seeds with only numerical differences among them, in which PUITA variety was the lowest value with $11,65 \%$ and the variety IRGA 428 was the highest with $19,16 \%$.

These results agree with Palacios and Pauth (2008), in an advanced evaluation of nine lines of rice with a spotted resistance, which also registered levels equivalents to a moderate resistance for all treatments, from $6.35 \%$ to $18.30 \%$.

Cárdenas et al., (2004) in a study of the behavior of spotted grain in different varieties of medium-cycle rice, registered similar levels for seeds exposed to rainy periods, with $19.46 \%$, reaching up to $53.83 \%$ for some varieties, agreeing in this way.

However, they differ with what was obtained by Rivero et al., (2012) who in a study of fungi associated with spotted grain in Cuba, mention that for the two evaluated campaigns, values of $52,3 \%$ and $76,5 \%$ were registered, with the same ones being a susceptible and highly susceptible denomination, respectively. 
Similarly, Pinciroli et al., (2014) in an evaluation of meteorological indexes and their incidence in the spotted of rice grains of different genotypes, mention having registered higher values with $49.6 \%$ and $49.5 \%$ for two agricultural years, and the same being equivalent to varieties susceptible to spotting. It is mentioned that in general terms the presence of most species (Epicoccum sp. Nigrospora sp., Cladosporium sp., Alternaria sp., Fusarium sp., y Bipolaris sp.) were influenced by the low temperature and the high precipitation.

Spotted grains is a very complex disease determined by pathogen-host-environment interaction, and where differences can be detected between varieties and times. In addition, there are differences related to the species of the pathogen and the quality of the control measures implemented (Cárdenas et al., 2004; Pinciroli et al., 2014; Rivero et al., 2012).

\section{Weight of 1000 seeds}

As regards the weight of 1000 seeds, significant statistical differences between the different varieties were present and, equally, between the categories studied, the values can be observed in Table 2. A coefficient of variation of $4.21 \%$ and $\mathrm{p}$-value of 0.0001 .

Table 2: Weight of 1000 seeds per category in the different varieties of rice studied. FCA-UNA. San Lorenzo, Paraguay. 2017.

TREATMENT WEIGHT OF 1000 SEEDS

\begin{tabular}{ll}
\hline Non-Spotted Seeds & $2,53 \mathrm{a}$ \\
PUITA & $2,56 \mathrm{a}$ \\
IRGA 424 & $2,53 \mathrm{a}$ \\
IRGA 428 & $2,29 \mathrm{~b}$ \\
IRGA 426 & \\
Spotted Seeds & $1,84 \mathrm{~d}$ \\
PUITA & $2,06 \mathrm{c}$ \\
IRGA 424 & $1,98 \mathrm{~cd}$ \\
IRGA 428 & $2,13 \mathrm{c}$ \\
IRGA 426 &
\end{tabular}

These results agree with those obtained by Cardenas et al., (2004) who, in a study of the behavior of spotted rice grain, found statistically significant differences between the healthy and spotted seeds weights (both during low rainy seasons and very rainy seasons), besides mentioning the importance of variety in relation to its rusticity against negative effect of rainy seasons.

They also agree with Velazquez and Formento (2013), who in a study of the effect of the Fusariosis on susceptible wheat varieties, they mention that the most affected variable by this pathogen was the weight of a thousand seeds and that this one registered a decrease up to $45.6 \%$ between healthy and diseased seeds.

Variations in yield components are attributed to both, pathogens incidences and environmental conditions and grain staining can result in about 40\% decrease in the weight (Adames 2014, Cárdenas 2004, Pinciroli et al., 2004).

\section{Germination and Viability}

The data obtained through the valuation of the percentage of the germination and viability of the irrigated rice seeds in the area of San Miguel, Department of Misiones - Paraguay, are presented in the Table 1. The coefficient of variation values for germination and viability were 8,84 and 9,89 respectively.

\begin{tabular}{llc} 
Table 1: Germination $(\%)$ of spotted $(\mathrm{S})$ and non-spotted (N.S) rice seeds from the area of San Miguel, Misiones - Paraguay. \\
\hline TREATMENT & $\begin{array}{l}\text { GERMINATION } \\
(\%)\end{array}$ & $\begin{array}{l}\text { VIABILITY } \\
(\%)\end{array}$ \\
\hline Non-Spotted Seeds & $94 \mathrm{ab}$ & $95 \mathrm{a}$ \\
PUITA & $94 \mathrm{a}$ & $99 \mathrm{ab}$ \\
IRGA 424 & $75 \mathrm{ab}$ & $92 \mathrm{bc}$ \\
IRGA 428 & $85 \mathrm{ab}$ & $89 \mathrm{ab}$ \\
IRGA 426 & & $66 \mathrm{e}$ \\
Spotted seeds & $19 \mathrm{c}$ & $79 \mathrm{~d}$ \\
PUITA & $48 \mathrm{abc}$ & $64 \mathrm{~cd}$ \\
IRGA 424 & $58 \mathrm{c}$ & $71 \mathrm{c}$ \\
IRGA 428 & $66 \mathrm{bc}$ & \\
IRGA 426 &
\end{tabular}

*means with the same letters do not differ from each other $(\mathrm{p}>0,05)$ by the Tukey test at $5 \%$ of probability of error

The analysis of variance of the variable germination showed that there are statistically significant differences between the evaluated treatments. It was possible to verify the variety of rice seeds without the presence of spotted in the glumes, presented superior results in respect to those affected by the spotted. Similarly, it can be evidenced for the viability of the analysis that there is a significant percentage reduction in those seeds with the presence of spotted in glumes. 
In the evaluation of the behavior of the non-spotted seeds, it is possible to observe that the variety IRGA 424 , presented the highest germination percentage without statistically differentiating among the other varieties. In addition, the presence of the spotting showed the highest percentage of germination followed by the variety IRGA 426.

Sempere and Santamarina (2013) states that, if the product is destined for seed, this can act as a transmitter of diseases, conferring problems in the first phenological stage of the plant and producing a lower percentage of germination and a smaller size of seedlings.

Also, Batalla (2014) emphasized that the main effects of spotted seeds are the decrease in germination, size of seedlings, and lower number of grains per panicle.

Likewise, Ou quoted by Pinciroli et al., (2003) mentions that there is a direct relationship between the development of fungi in the seed and the germination of the seed, and that the diseases occur in seedlings such as blight and damping off.

In respect to viability, it was observed that within the group of non-spotted seeds varieties higher percentages were showed by the variety IRGA 424, followed by the IRGA 426, being the most affected by the spotting in glumes the PUITA variety with the lowest percentage of said variable.

Albuquerque et al. (2012), indicates that the main effect of storage and some field fungi is to reduce the viability of the seeds with moisture content above the critical value. In addition, it mentions colonization occurs initially in the region of the embryo, being able to degrade the whole seed.

The pathogens associated to the seeds can cause direct damages, causing field losses due to reduced productivity (Albuquerque et al. 2012).

Estrada and Sandoval cited by Cárdenas et al., 2004, states that spotted grain is a very complex disease, determined by pathogen-host-environment interaction, and this explains the observed reduction in the quality of the seeds obtained in the period 2015/2016, since there was high rainfall level that possibly increased favorable conditions for the development and dissemination of phytopathogens.

Consequently, spotted of the glumes in rice during wet and rainy periods, causes subsequent damages by reducing the quality of the rice.

\section{Conclusions}

There are no differences related to the percentage of spotted seeds among the various rice used in the experiment.

In relation to the weight variable of 1000 seeds there is a marked difference between the seeds with visual presence of symptoms of the spotting and those healthy seeds, for all the varieties used.

Non-spotted seeds varieties IRGA 424, IRGA 428 and PUITA were the best performing with the highest weights. On the other hand, the PUITA and IRGA 428 spotted seed varieties showed the lowest values for this variable.

The spotted seeds caused by a complex of pathogens significantly affects the weight variables as well as germination and vigor of the rice seeds (Oryza sativa L.) corresponding to the varieties of IRGA 424, IRGA 428, IRGA 426 and PUITA.

The IRGA 424 rice variety shows better performance or spotted behavior in terms of germination and viability.

The climatic conditions presented in Paraguay during the last years are characterized by high temperatures during more hours of the day, drought and much stronger rains, these would be some of the factors or causes that favored a favorable microclimate for the establishment and development of the different fungi associated with spotted seeds of rice

It is of utmost importance to understand the impact it could cause, since these seeds carrying pathogenic fungi, can provide inoculum, which under optimum conditions could initiate and epidemic and decrease yields by working with susceptible varieties or by not performing an adequate integrated management, in addition to the possibility of introducing pathogens to areas free of them.

\section{REFERENCES}

Adames, A., 2014. Evaluación de genotipos de arroz por épocas de siembra en la zona nordeste de la Republica Dominicana. Revista Agropecuaria y Forestal., 3(1): 9-16.

Aguilar, M. 2001. Cultivo del arroz en el sur de España. Centro de Investigación e Información Agraria, Sevilla, p:189.

Albuquerque Barros, A. C. S., Chiesa Freitas, D. A., Brod Pres, and Casas Navarro Zanatta, Z. G. 2012. Compilaçao de monografías em ciência y tecnologia de sementes: turmas editar CNPQ/MAPA/SDA 064-2008. Pelotas: Ed. Universitaria, UFPEL. p: 836.

Arriagada, V., 2000. Semillas, Inspección, análisis, tratamiento y legislación. IICA, Santiago, Chile. p:114 
Batalla A., 2014. Incidencia del manchado de grano en arroz. (http://www.latranqueraweb.com.ar/web/archivos/menu/Incidencia_del_manchado_de_grano_en_arroz.pdf). Accessed on 12/05/2017.

Cárdenas, R; Valdez, E; Pérez, N; González, M; Rivero, D; Cruz, A. 2004. Comportamiento del manchado del grano en variedades de arroz de ciclo medio. Fitosanidad, 9(4): 39-44.

Castaño, Z., J. 1985. Efecto del manchado del grano de arroz sobre algunos estados de desarrollo de la planta de arroz, 34(338): 22-26.

INVESTOR, 2015. Informe Agrícola Semestral. Unión de Gremios de la Producción, Asunción, Paraguay, p: 15 .

ISTA (International Seed Testing Association), SW. 2011. International rules for sedd testing. Zurich, Switzerland. p: 159.

MAG (Ministerio de Agricultura y Ganadería), 2016. Dpto. de Estadísticas/DCEA, datos de Encuestas Agrícolas, Sub Centros de la DCEA y DEAg/MAG e informantes calificados.

Mazzanti de Castañón, M.A., Gutiérrez de Arriola S.A., 2001. Hongos asociados a granos manchados de arroz. En: 6ta Reunión de Comunicaciones Científicas y Técnicas, Facultad de Ciencias Agrarias, UNNE, Corrientes, Argentina. Resúmenes, p: 129. 8.

Morejón, R., Hernández J.J., Díaz S.H., 2005. Comportamiento de variedades comerciales de arroz (Oryza sativa L.) en cuatro granjas del Complejo Agroindustrial Arrocero "Los Palacios". Cultivos Tropicales, 26: 7781.

Pérez, N., González M.C., Castro R.I., 2002. Validación de nuevas variedades cubanas de arroz (Oryza sativa L.) para la provincia de Pinar del Río. Cultivos Tropicales, 23: 51-4.

Pinciroli, M., Sisterna M., Bezus R., Vidal A., 2004. Manchado del grano de arroz: efecto de la fertilización nitrogenada. Revista de la Facultad de Agronomía - La Plata, 105(2): 88-96.

Pineda, J.B., Colmenárez O., Méndez N., L. Gutiérrez, 2007. Niveles de inóculo de hongos fitopatógenos asociados a la semilla de arroz (Oryza sativa). Rev. Fac. Agron., 24: 481-500.

Regla, M., Cárdenas Travieso E., Valdés C., Pérez León, M., González Vázquez, D., Rivero González and Cruz Triana A., 2004. Comportamiento del manchado del grano en variedades de arroz (Oryza sativa) de ciclo medio. Instituto Nacional de Ciencia Agrícolas. San José de las Lajas, La Habana, Cuba.

Rivero, D., Cruz A., Rodríguez A., Echevarría A., Martínez B., 2012. Hongos asociados al manchado del grano en la variedad de arroz INCA LP-5 (Oryza sativa) en Cuba. Revista de la Sociedad Venezolana de Microbiología, 33(1): 131-138.

Velázquez, P. and Formento, A. N., 2013. Efecto de la fusariosis de la espiga del trigo (Fusarium graminearum y Fusarium spp.) en un cultivar susceptible. Campaña 2012. Paraná, Entre Ríos. Jornada Regional de Cultivos de Invierno. Campaña 2013. FCA-UNER. pp: 45-48. 